\title{
Mass Transfer Correlation and Optimization of Carbon Dioxide Capture in a Microchannel Contactor: A Case of $\mathrm{CO}_{2}$-Rich Gas
}

\author{
Nattee Akkarawatkhoosith ${ }^{1} \oplus$, Wannarak Nopcharoenkul ${ }^{2}$, Amaraporn Kaewchada ${ }^{2}$ \\ and Attasak Jaree ${ }^{3, *}$ \\ 1 Department of Chemical Engineering, Faculty of Engineering, Mahidol University, \\ 25/25 Phuttamonthon 4 Road, Nakhon Pathom 73170, Thailand; nattee.akk@mahidol.edu \\ 2 Department of Agro-Industrial, Food and Environmental Technology, King Mongkut's University \\ of Technology North Bangkok, Pracharat 1 Road, Wongsawang, Bansue, Bangkok 10800, Thailand; \\ wannarak.n@sci.kmutnb.ac.th (W.N.); amaraporn.k@sci.kmutnb.ac.th (A.K.) \\ 3 Department of Chemical Engineering, Faculty of Engineering, Kasetsart University, Chatuchak, \\ Bangkok 10900, Thailand \\ * Correspondence: fengasj@ku.ac.th
}

Received: 12 September 2020; Accepted: 17 October 2020; Published: 19 October 2020

\begin{abstract}
This work focused on the application of a microchannel contactor for $\mathrm{CO}_{2}$ capture using water as absorbent, especially for the application of $\mathrm{CO}_{2}$-rich gas. The influence of operating conditions (temperature, volumetric flow rate of gas and liquid, and $\mathrm{CO}_{2}$ concentration) on the absorption efficiency and the overall liquid-side volumetric mass transfer coefficient was presented in terms of the main effects and interactions based on the factorial design of experiments. It was found that $70.9 \%$ of $\mathrm{CO}_{2}$ capture was achieved under the operating conditions as follows; temperature of $50{ }^{\circ} \mathrm{C}, \mathrm{CO}_{2}$ inlet fraction of $53.7 \%$, total gas volumetric flow rate of $150 \mathrm{~mL} \mathrm{~min}^{-1}$, and adsorbent volumetric flow rate of $1 \mathrm{~mL} \mathrm{~min}{ }^{-1}$. Outstanding performance of $\mathrm{CO}_{2}$ capture was demonstrated with the overall liquid-side volumetric mass transfer coefficient of $0.26 \mathrm{~s}^{-1}$. Further enhancing the system by using 2.2 M of monoethanolamine in water (1:1 molar ratio of MEA-to- $\left.\mathrm{CO}_{2}\right)$ boosted the absorption efficiency up to $88 \%$.
\end{abstract}

Keywords: $\mathrm{CO}_{2}$ capture; microchannel; absorption; $\mathrm{CO}_{2}$-rich gas

\section{Introduction}

High concentration of carbon dioxide in the synthesis gas or biogas product is one of the major issues regarding the environmental pollution (greenhouse effect) and fuel quality, leading to the requirement of post-treatment process(es) for $\mathrm{CO}_{2}$ removal. For instance, high $\mathrm{CO}_{2}$ content in biogas degrades the fuel quality such as the calorific value and anti-knock properties of engine [1]. Over the past decades, many $\mathrm{CO}_{2}$ separation methods have been proposed such as absorption, adsorption, and membrane separation [2]. Among these methods, $\mathrm{CO}_{2}$ absorption is the most widely used due to the relatively lower operating cost and higher efficiency [3]. However, amid the successes, the use of toxic chemical solvents has been involved, causing serious impact on the environment (corrosion) and economic sustainability.

A wide range of toxic solvents have been reported for the use of $\mathrm{CO}_{2}$ removal with the high absorption capacity such as monoethanolamine (MEA) and diethanolamine (DEA) [3,4]. Various achievements of highly effective $\mathrm{CO}_{2}$ capture have been reported. For example, Sahraie et al. [5] investigated the effect of absorption variables on the $\mathrm{CO}_{2}$ absorption efficiency using MEA concentration in the range of 15-30 wt.\%. It was found that the maximum of absorption efficiency (95\%) was obtained 
with the requirement of $30 \mathrm{wt} . \%$ MEA. Similar results were reported for the use of high MEA concentration [6,7] (3-6 M) to achieve high absorption rate. The high concentration of solvent in the process raised an environmental concern. Moreover, the requirement of solvent purification and regeneration is associated with additional investment and operation costs [8].

A process of $\mathrm{CO}_{2}$ removal can be carried out using various types of unit operation such as bubble column, packed column, and tray column. Such macro-scale equipment is inherently associated with the low mass transfer coefficient [9]. Another type of contactor known as microreactor has been applied as a promising tool for enhancing the mass transfer coefficient in various applications particularly in multi-phase systems. Conceivably, the intensification of $\mathrm{CO}_{2}$ absorption could be achieved using a microtube contactor. Moreover, the issue of high solvent consumption could be alleviated with this technique as demonstrated in our previous work [10], in which microreactor technology was employed to enhance the $\mathrm{CO}_{2}$ capture process, particularly for $\mathrm{CO}_{2}$-rich gas application. Although our process exhibited the superior absorption efficiency $\left(97 \%, 0.8 \mathrm{~mol} \mathrm{~m}^{-2} \mathrm{~s}^{-1}\right)$ compared to the conventional reactors, the concentration of solvent was still high (4.3 M MEA). This hurdle could be handled by applying the eco-friendly solvent along with the microreactor technology.

Recently, ionic liquids as a green solvent have been reported for enhancing the $\mathrm{CO}_{2}$ absorption efficiency [9]. However, the high solvent cost is still the barrier for industrial applications. Among others, water is considered as the most promising solvent for $\mathrm{CO}_{2}$ absorption. Although this solvent exhibits relatively low $\mathrm{CO}_{2}$ absorption efficiency [11], it provides many important features for industrial applications such as being eco-friendly and readily available as well as allowing for simple unit operation. Hence, the process intensification for this solvent should be further investigated.

In the $\mathrm{CO}_{2}-\mathrm{H}_{2} \mathrm{O}$ separation process, the overall liquid-side volumetric mass transfer coefficient $\left(\mathrm{K}_{\mathrm{L}}\right)$ is the significant factor in determining the absorption efficiency since the major mass transfer resistance lies in the liquid phase [12]. This coefficient is strongly influenced by the operating conditions and flow characteristics in the system. For example, the enhancement of $\mathrm{CO}_{2}-\mathrm{H}_{2} \mathrm{O}$ process using ultrasonic contactor [13] was demonstrated to reduce the mass transfer resistance and to enhance the absorption rate. However, the feed concentration of $\mathrm{CO}_{2}$ was limited at $30 \mathrm{vol} \%$ which was not in the range for $\mathrm{CO}_{2}$-rich gas applications. Therefore, the application of microreactor for $\mathrm{CO}_{2}-\mathrm{H}_{2} \mathrm{O}$ absorption process should be extended to enhance $\mathrm{CO}_{2}$ absorption efficiency for $\mathrm{CO}_{2}$-rich gas applications.

The highlight of this research was to propose the simple and effective process for $\mathrm{CO}_{2}$ capture, particularly for $\mathrm{CO}_{2}$-rich gas (40-60 vol.\%). In this work, microchannel technology was applied to enhance the $\mathrm{CO}_{2}$ absorption efficiency for the $\mathrm{CO}_{2}$-rich gas, which has not been investigated. Water was used as a green solvent. The effect of operating parameters on the absorption efficiency was investigated and the optimization via experimental design was carried out. The mass transfer coefficient was determined, and the reactor performance was compared with that of other absorbers based on the literature data. This investigation could provide an important information for applying with the other $\mathrm{CO}_{2}$ absorption systems using water. In addition, we demonstrated the improved performance of $\mathrm{CO}_{2}$ absorption by using low concentration of solvent (MEA).

\section{Materials and Methods}

\subsection{Materials}

The gases with high purity of $\mathrm{CO}_{2}(99.99 \%)$ and $\mathrm{N}_{2}$ (99.99\%) were supplied by Praxair (Thailand) and Linde (Thailand), respectively. Water was used as a green absorbent. The $\mathrm{CO}_{2}-\mathrm{N}_{2}$ mixture (40-60 vol.\%) was used to simulate high $\mathrm{CO}_{2}$ content gas at various $\mathrm{CO}_{2}$ concentration levels.

In this work, the rectangular microchannel made of aluminum alloy (AA1050) was used as a $\mathrm{CO}_{2}$ micro-contactor. The microchannel contactor system consisted of five sections including the inlet channels for $\mathrm{CO}_{2}$ gas mixture and absorbent, T-micromixer $(500 \mu \mathrm{m})$ where the fluid streams were mixed, microchannel for $\mathrm{CO}_{2}$ capture (500 $\mu \mathrm{m}$ in width $\times 500 \mu \mathrm{m}$ in depth $\times 60 \mathrm{~mm}$ in length) where the $\mathrm{CO}_{2}-\mathrm{H}_{2} \mathrm{O}$ absorption occurred, gas-liquid separation chamber, and outlet channels for gas 
and liquid streams. The microchannel contactor system and experimental set-up for $\mathrm{CO}_{2}$ absorption is shown in Figure 1.

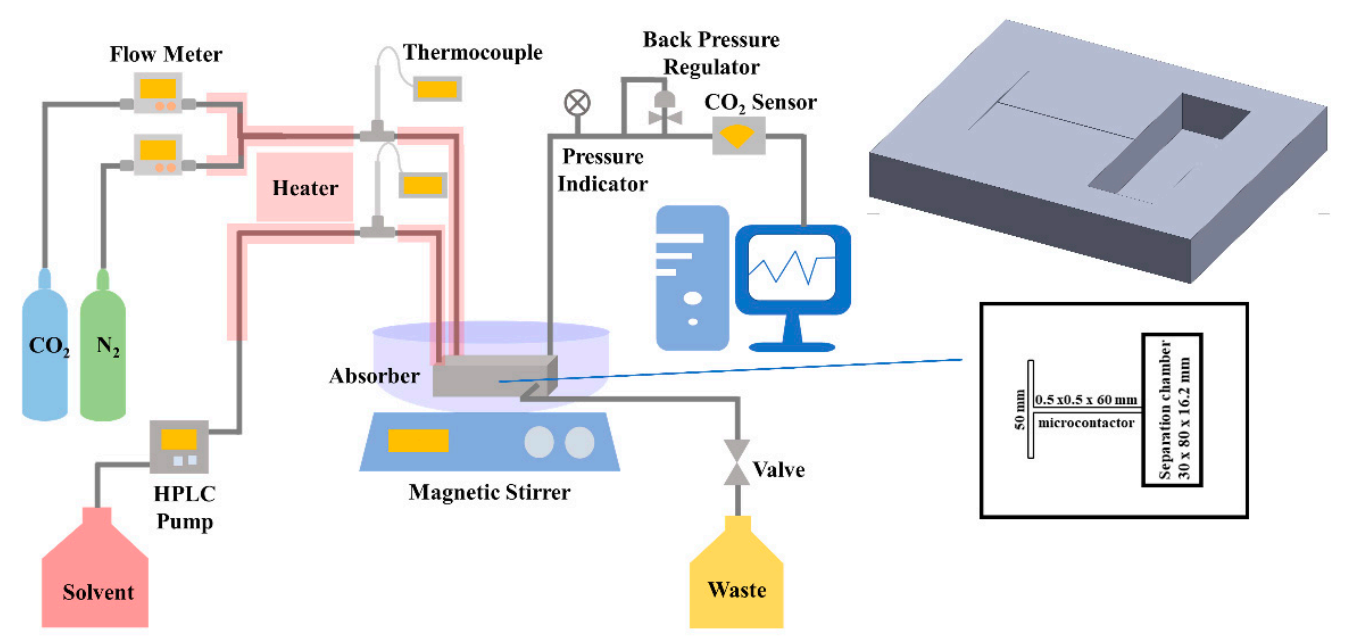

Figure 1. Equipment and experimental set-up for $\mathrm{CO}_{2}$ absorption process.

\section{2. $\mathrm{CO}_{2}$ Capture Process}

In this work, nitrogen and $\mathrm{CO}_{2}$ were separately fed to the system via individual mass flow controllers. These two streams combined at a T-mixer to obtain a $\mathrm{CO}_{2}-\mathrm{N}_{2}$ gas mixture at a specific ratio or concentration. A stream of water (green solvent) was fed via an HPLC pump to mix with the $\mathrm{CO}_{2}-\mathrm{N}_{2}$ gas mixture at another T-mixer located in the front section of $\mathrm{CO}_{2}$ absorber. Note that both streams were separately preheated to the desired temperature prior to entering in the T-micromixer. The absorption process took place in the microtube contactor which was immersed in a hot water bath to control the absorption temperature. The exit-end of the microtube was connected to a separator that has two outlets; one for gas product and another for liquid product. The pressure of the system was controlled by means of a back-pressure regulator connected to the gas product stream. The gas mixture exiting through the back-pressure regulator was analyzed for $\mathrm{CO}_{2}$ content using a $\mathrm{CO}_{2}$ detector (COZIR Wide Range GC-0016). The absorption pressure was kept constant at 1.7 bar. Note that, the effect of pressure was assumed negligible in our system. The valve for liquid product was adjusted to ensure that no liquid was accumulated in the separator where the $\mathrm{CO}_{2}$ mass transfer was neglected due to the very short contact time of $\mathrm{CO}_{2}$ and water. The experimental range of absorption variables are summarized in Table 1.

Table 1. Experimental range of absorption variables.

\begin{tabular}{lccccc}
\hline \multirow{2}{*}{ Variable } & \multirow{2}{*}{ Unit } & Symbol & \multicolumn{4}{c}{ Range and Level } \\
\cline { 4 - 6 } & & & $-\mathbf{1}$ & $\mathbf{0}$ & $\mathbf{1}$ \\
\hline Independent Variables & & & & & \\
\hline $\mathrm{CO}_{2}$ Fraction & vol.\% & $\mathrm{F}$ & 40 & 50 & 60 \\
Total gas volumetric flow rate & $\mathrm{mL} \mathrm{min}^{-1}$ & $\mathrm{G}$ & 150 & 175 & 200 \\
Liquid volumetric flow rate & $\mathrm{mL} \mathrm{min}^{-1}$ & $\mathrm{~L}$ & 1.0 & 1.5 & 2.0 \\
Temperature & ${ }^{\circ} \mathrm{C}$ & $\mathrm{T}$ & 30 & 40 & 50 \\
\hline Dependent Variable & & & & & \\
\hline \%Absorption & $\% \mathrm{E}$ & $\%$ & & & \\
\hline
\end{tabular}




\subsection{Mass Transfer Coefficient Calculation}

In this work, the physicochemical absorption took place in the $\mathrm{CO}_{2}-\mathrm{H}_{2} \mathrm{O}$ absorption system. The absorption of $\mathrm{N}_{2}$ in water was neglected in this work since the $\mathrm{N}_{2}$ can barely dissolve in water. The transport phenomena of $\mathrm{CO}_{2}$ can be described based on the two-film theory. First, $\mathrm{CO}_{2}$ from the bulk gas phase is transferred into the gas film. Then $\mathrm{CO}_{2}$ diffuses into the gas-liquid interface and is subsequently transferred across the liquid film out into the bulk of liquid. Hence, the $\mathrm{CO}_{2}$ mass transfer flux $\left(\mathrm{N}_{\mathrm{CO}_{2}}\right)$ can be calculated via Equations (1) and (2).

$$
\begin{gathered}
\mathrm{N}_{\mathrm{CO}_{2}}=\frac{\mathrm{n}_{\mathrm{CO}_{2} \text {,in }}-\mathrm{n}_{\mathrm{CO}_{2} \text {,out }}}{a V_{\mathrm{R}}} \\
\mathrm{N}_{\mathrm{CO}_{2}}=\mathrm{k}_{\mathrm{G}}\left(\mathrm{P}_{\mathrm{CO}_{2}}^{\text {bulk }}-\mathrm{P}_{\mathrm{CO}_{2}}^{\mathrm{i}}\right)=\mathrm{k}_{\mathrm{L}}\left(\mathrm{C}_{\mathrm{CO}_{2}}^{\mathrm{i}}-\mathrm{C}_{\mathrm{CO}_{2}}^{\text {bulk }}\right)
\end{gathered}
$$

where $\mathrm{n}_{\mathrm{CO}_{2}}$ is the mole of $\mathrm{CO}_{2}$; a is the gas-liquid interfacial area per unit reactor volume; $\mathrm{V}_{\mathrm{R}}$ is the reactor volume; and $\mathrm{k}_{\mathrm{G}}$ and $\mathrm{k}_{\mathrm{L}}$ are the individual gas-side and liquid-side mass transfer coefficient, respectively. In our absorption system, the gas-side mass transfer coefficient could be neglected due to the low solubility of $\mathrm{CO}_{2}$ in water. Consequently, the overall liquid-side mass transfer coefficient $\left(\mathrm{K}_{\mathrm{L}}\right)$ was approximately equal to the liquid-side mass transfer coefficient $\left(\mathrm{k}_{\mathrm{L}}\right)$. Since the concentration of $\mathrm{CO}_{2}$ at the gas-liquid interface is not readily measurable, the $\mathrm{CO}_{2}$ absorption flux can be expressed in terms of $\mathrm{CO}_{2}$ concentration $\left(\mathrm{C}_{\mathrm{CO}_{2}}^{\mathrm{i}}\right)$ and the overall liquid-side mass transfer coefficient $\left(\mathrm{K}_{\mathrm{L}}\right)$ (see Equation (3)). Henry's Law was used to describe the linear relationship between the partial pressure of $\mathrm{CO}_{2}$ in the gas phase and $\mathrm{C}_{\mathrm{CO}_{2}}^{\mathrm{i}}$ (Equation (4) [14]).

$$
\begin{gathered}
\mathrm{N}_{\mathrm{CO}_{2}}=\mathrm{K}_{\mathrm{L}}\left(\mathrm{C}_{\mathrm{CO}_{2}}^{\mathrm{i}}-\mathrm{C}_{\mathrm{CO}_{2}}^{\text {bulk }}\right) \\
\mathrm{C}_{\mathrm{CO}_{2}}^{\mathrm{i}}=\mathrm{H}_{\mathrm{CO}_{2}} \mathrm{P}_{\mathrm{CO}_{2}}
\end{gathered}
$$

where $\mathrm{H}_{\mathrm{CO}_{2}}$ is the Henry's coefficient. The average pressure of $\mathrm{CO}_{2}$ in the bulk gas can be expressed in terms of a logarithmic mean pressure difference based on the inlet and outlet conditions [15] as shown in Equation (5).

$$
\mathrm{P}_{\mathrm{CO}_{2}}^{\text {bulk }}=\left(\frac{\mathrm{P}_{\mathrm{CO}_{2, \text { in }}}^{\text {bulk }}-\mathrm{P}_{\mathrm{CO}_{2, \text { out }}^{\text {bulk }}}}{\ln \left(\frac{\mathrm{P}_{\mathrm{Cl}_{2, \text { in }}}^{\text {blu }}}{\mathrm{P}_{\mathrm{CO}_{2, \text { out }} \text { bulk }}}\right)}\right)
$$

The Henry constant and diffusion coefficient of $\mathrm{CO}_{2}$ in $\mathrm{H}_{2} \mathrm{O}$ as a function of temperature were obtained from the literature by Versteeg and Swaaij [16], and Karlsson and Svensson [17] (Equations (6) and (7)). The absorption efficiency is expressed in Equation (8).

$$
\begin{gathered}
\mathrm{H}_{\mathrm{CO}_{2}}=3.54 \times 10^{-7} \exp \left(\frac{2044}{\mathrm{~T}}\right) \\
\mathrm{D}_{\mathrm{CO}_{2}-\mathrm{H}_{2} \mathrm{O}}=2.35 \times 10^{-6} \exp \left(\frac{-2119}{\mathrm{~T}}\right) \\
\% \text { absorption efficiency }=\left(\frac{\mathrm{n}_{\mathrm{CO}_{2} \text {,in }}-\mathrm{n}_{\mathrm{CO}_{2} \text {,out }}}{\mathrm{n}_{\mathrm{CO}_{2} \text {,in }}}\right) \times 100
\end{gathered}
$$

\section{Results and Discussion}

\subsection{Main Effect of Absorption Variables}

The main effect of variables including the amount of $\mathrm{CO}_{2}$, volumetric flow rate of water, volumetric flow rate of gas mixture, and absorption temperature on the mean absorption efficiency $(\%)$ 
was evaluated based on the $3^{\mathrm{k}}$ factorial design (see Table 1). The main effect results shown in Figure 2a indicate a strong negative effect on the mean absorption efficiency when either the volumetric flow rate of liquid or gas was increased. This was due to the short absorption time (contact time) between gas phase and liquid phase. A similar trend was observed for the overall liquid-side volumetric mass transfer coefficient $\left(\mathrm{K}_{\mathrm{L}} \mathrm{a}\right)$ (see Figure $2 \mathrm{~b}$ ) which decreased by increasing the volumetric flow rate. To further describe this behavior, the effect of volumetric flow rates of gas (150 to $200 \mathrm{~mL} \mathrm{~min}{ }^{-1}$ ) and liquid ( 1 to $2 \mathrm{~mL} \mathrm{~min}^{-1}$ ) on the absorption efficiency was plotted when other variables were held constant $\left(\mathrm{CO}_{2}\right.$ inlet fraction of 0.5 and absorption temperature of $\left.40^{\circ} \mathrm{C}\right)$ as shown in Figure 3 . The significant decline of absorption efficiency was observed when the volumetric flow rate of liquid was increased. For instance, at the volumetric flow rate of gas of $175 \mathrm{~mL} \mathrm{~min}{ }^{-1}$, the absorption efficiency was dramatically reduced from $62.1 \%$ to $16.2 \%$ when the volumetric flow rate of liquid was increased from $1 \mathrm{~mL} \mathrm{~min}^{-1}$ to $2 \mathrm{~mL} \mathrm{~min}^{-1}$, resulting in the poor mass transfer rate of $\mathrm{CO}_{2}$ to water (see Figure 3b). Similar behavior was observed when the total flow rate of liquid was increased instead of the volumetric flow rate of liquid (Figure 3).

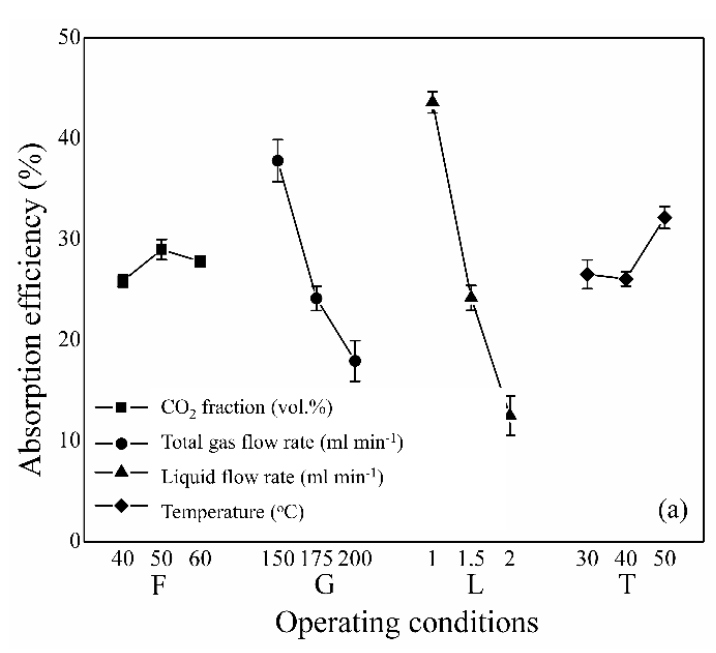

Figure 2. Main effect of absorption variables on the responses; (a) absorption efficiency, (b) overall liquid-side mass transfer coefficient.

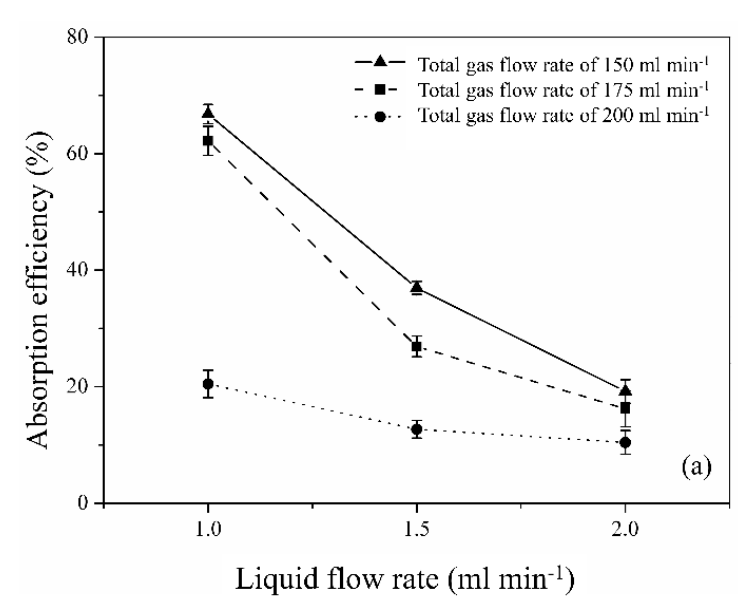

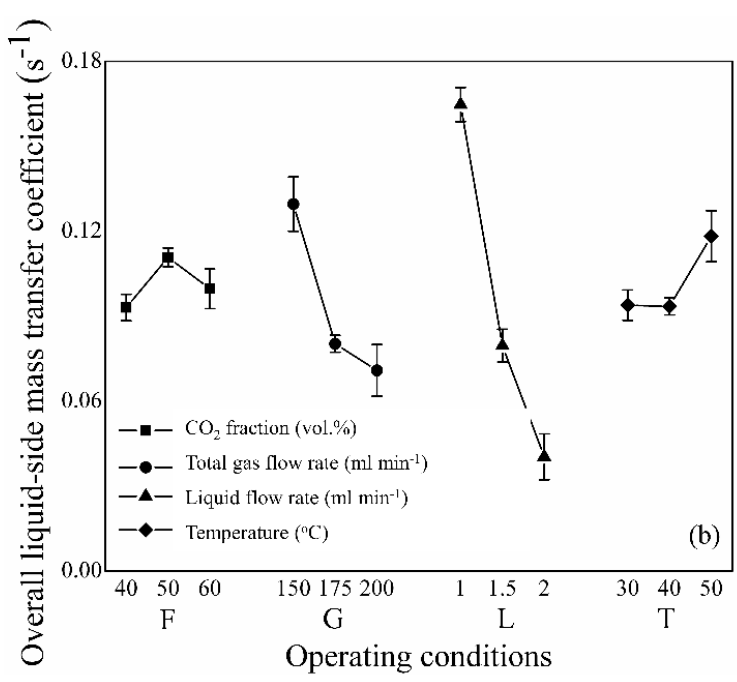

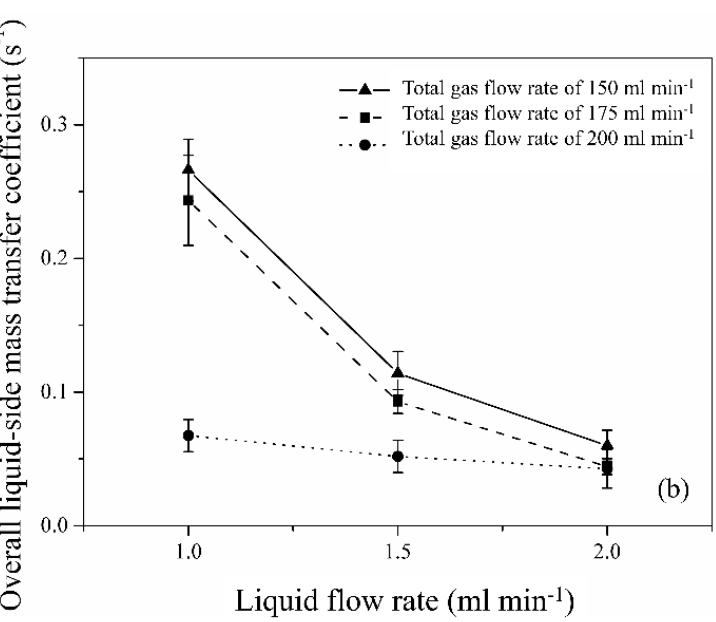

Figure 3. Effects of total flow rate of gas and liquid on the responses: (a) absorption efficiency, (b) overall liquid-side mass transfer coefficient. 
For high $\mathrm{CO}_{2}$ concentration level, the adsorption capacity of $\mathrm{CO}_{2}$ in water proceeded via the hydration reaction. The series of reactions involved were as follows:

$$
\begin{gathered}
\mathrm{CO}_{2}(\mathrm{~g}) \leftrightarrow \mathrm{CO}_{2}(\mathrm{aq}) \\
\mathrm{CO}_{2}(\mathrm{aq})+\mathrm{H}_{2} \mathrm{O} \leftrightarrow \mathrm{H}_{2} \mathrm{CO}_{3}
\end{gathered}
$$

These reactions could enhance both the solubility of $\mathrm{CO}_{2}$ in water and the absorption efficacy. In order to confirm this, a separate $\mathrm{CO}_{2}$ absorption experiment was carried out while the conductivity of the liquid stream exiting the $\mathrm{CO}_{2}$ absorption apparatus was monitored. The operating conditions were at $40 \%$ of $\mathrm{CO}_{2}$ inlet concentration, temperature of $30^{\circ} \mathrm{C}, 150 \mathrm{~mL} \mathrm{~min}^{-1}$ of gas flow rate, and $1 \mathrm{~mL} \mathrm{~min}^{-1}$ of liquid flow rate. The conductivity probe was placed inside a round-bottom glass tube with two ports on the side; one for the incoming liquid stream from the apparatus located near the bottom and another one (located at the position such that the probe was sufficiently immersed) for output stream going to the waste collector. The tube was initially filled with deionized water. It was observed that the conductivity of liquid stream significantly rose from $4.4 \mu \mathrm{S} \mathrm{cm}^{-1}$ (pure DI water) and reached equilibrium at $37.5 \mu \mathrm{S} \mathrm{cm}^{-1}$. The change in conductivity of the water was due to the existence of bicarbonate ion (carbonic acid). Note that, the $\mathrm{CO}_{2}$ (aq) in water cannot increase the conductivity of the water. This observation was also in line with the work of Bhaduri et al. [18] who investigated the improvement of $\mathrm{CO}_{2}$ capture by enhancing the $\mathrm{CO}_{2}$ hydration reaction. The high rate of $\mathrm{CO}_{2}$ hydration was evidently observed when the pure $\mathrm{CO}_{2}$ was used.

The low impact on the mean absorption efficiency was observed for the cases of the absorption temperature and $\mathrm{CO}_{2}$ fraction in the feed (Figure 2). In case of absorption temperature, the absorption efficiency was approximately unchanged at temperatures below $40^{\circ} \mathrm{C}$ and slightly increased at $50{ }^{\circ} \mathrm{C}$. This behavior involved the change of physical properties of $\mathrm{CO}_{2}$ with temperature. For instance, increasing temperature can help increase the $\mathrm{CO}_{2}$ diffusion coefficient [19]; however, the content of $\mathrm{CO}_{2}$ dissolved in water $\left(\mathrm{CO}_{2}\right.$ solubility) is also decreased [20,21]. This means that the effect of diffusion was dominant over the effect of solubility at high absorption temperature. For the effect of $\mathrm{CO}_{2}$ inlet fraction, the mean absorption efficiency improved when the $\mathrm{CO}_{2}$ inlet fraction increased from $40 \%$ to $50 \%$ due to the large mass transfer flux $\left(\mathrm{N}_{\mathrm{CO}_{2}}\right)$ as a result of high $\mathrm{CO}_{2}$ feed concentration as a driving force (see Equation (3)). Further increasing in the $\mathrm{CO}_{2}$ feed concentration (up to $60 \%$ ) led to a slight decline of $\mathrm{CO}_{2}$ absorption efficiency, as the system was approaching the limit of $\mathrm{CO}_{2}$ solubility in water. These findings were confirmed when plotting the $\mathrm{CO}_{2}$ inlet fraction (40 to $60 \%$ ) with the absorption temperature $\left(30\right.$ to $50^{\circ} \mathrm{C}$ ) while holding the volumetric flow rate of $175 \mathrm{~mL} \mathrm{~min}^{-1}$ and $1.5 \mathrm{~mL} \mathrm{~min}^{-1}$ for gas and liquid streams, respectively (Figure 4). At the same $\mathrm{CO}_{2}$ inlet fraction, a slight effect of reaction temperature on the absorption efficiency was observed. For the case of $\mathrm{CO}_{2}$ fraction, the highest absorption efficiency was obtained for the $\mathrm{CO}_{2}$ inlet fraction of $50 \%$. 

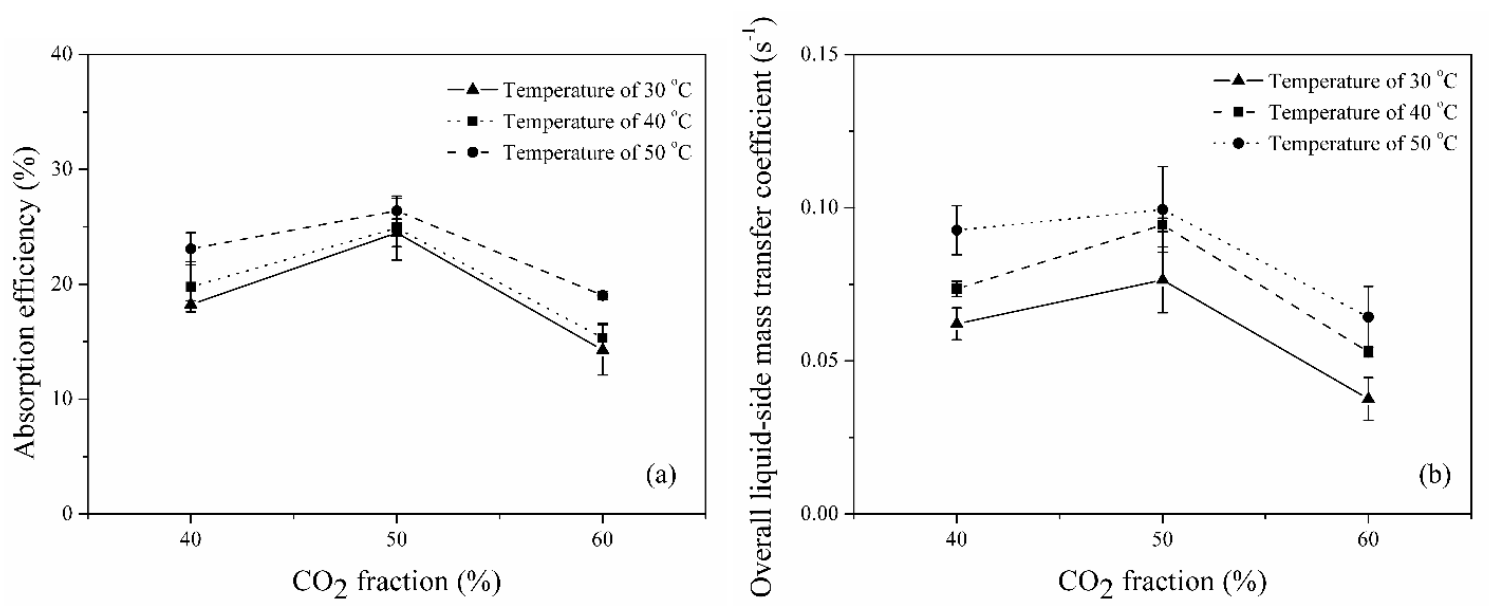

Figure 4. Effects of $\mathrm{CO}_{2}$ fraction and absorption temperature on the responses: (a) absorption efficiency, (b) overall liquid-side mass transfer coefficient.

\subsection{Interaction Effect of Absorption Variables}

The interaction effect of absorption variable pairs can be elaborated through both P-value and contour plot. When the P-value is larger than 0.05 or the slope of contour line is straight and parallel, the interaction effect is not statistically significant. The ANOVA results as shown in Table 2 indicate that the interaction effect between the total gas volumetric flow rate $(G)$ and liquid volumetric flow rate (L) was statistically significant. This behavior was related to the contact time between gas phase and liquid phase which was inversely proportional to the volumetric flow rate. The contact time was relatively shorter at high volumetric flow rate of gas and high volumetric flow rate of liquid, and vice versa. The contour plot of this variable pair is shown in Figure 5a. At high level of the total gas volumetric flow rate, the absorption efficiency increased slightly with decreasing volumetric flow rate of liquid. A similar behavior was observed with higher sensitivity at low level of the total gas volumetric flow rate, signifying the interaction effect of these variables.

Table 2. ANOVA results for $3^{\mathrm{k}}$ factorial design.

\begin{tabular}{lccccc}
\hline Variable & DF & Seq SS & Adj SS & Adj MS & $p$-Value \\
\hline F & 2 & 216.96 & 216.96 & 108.48 & 0.144 \\
G & 2 & 6587.36 & 6587.36 & 3293.68 & 0 \\
$\mathrm{~L}$ & 2 & $12,334.79$ & $12,334.79$ & 6167.4 & 0 \\
$\mathrm{~T}$ & 2 & 665.8 & 665.8 & 332.9 & 0.008 \\
$\mathrm{~F} \times \mathrm{G}$ & 4 & 314.59 & 314.59 & 78.65 & 0.225 \\
$\mathrm{~F} \times \mathrm{L}$ & 4 & 52.59 & 52.59 & 13.15 & 0.895 \\
$\mathrm{~F} \times \mathrm{T}$ & 4 & 302.21 & 302.21 & 75.55 & 0.241 \\
$\mathrm{G} \times \mathrm{L}$ & 4 & 1410.61 & 1410.61 & 352.65 & 0.002 \\
$\mathrm{G} \times \mathrm{T}$ & 4 & 282.32 & 282.32 & 70.58 & 0.27 \\
$\mathrm{~L} \times \mathrm{T}$ & 4 & 146.72 & 146.72 & 36.68 & 0.577 \\
$\mathrm{~F} \times \mathrm{G} \times \mathrm{L}$ & 8 & 216.02 & 216.02 & 27 & 0.805 \\
$\mathrm{~F} \times \mathrm{G} \times \mathrm{T}$ & 8 & 920.61 & 920.61 & 115.08 & 0.071 \\
$\mathrm{~F} \times \mathrm{L} \times \mathrm{T}$ & 8 & 495.67 & 495.67 & 61.96 & 0.332 \\
$\mathrm{G} \times \mathrm{L} \times \mathrm{T}$ & 8 & 634.36 & 634.36 & 79.3 & 0.2 \\
Error & 16 & 790.51 & 790.51 & 49.41 & \\
Total & 80 & $25,371.12$ & & & \\
\hline
\end{tabular}



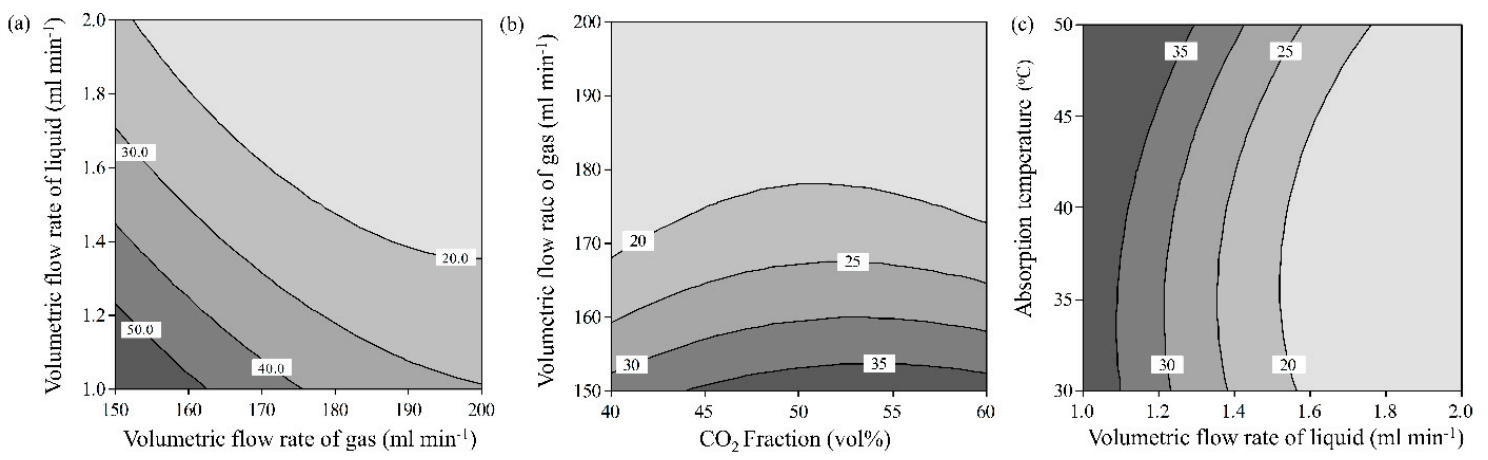

Figure 5. Interaction effect of variable pairs; (a) volumetric flow rate of gas and liquid, (b) volumetric flow rate of gas and $\mathrm{CO}_{2}$ fraction, (c) volumetric flow rate of liquid and temperature.

On the contrary, the interaction effect of other variable pairs was not statistically significant due to the large $p$-value (>0.05). This was confirmed by the contour plots in Figure $5 b, c$.

\subsection{Flow Pattern of $\mathrm{CO}_{2}$ Capture Process}

According to the literature, the superficial velocity of liquid and gas plays an important role on the gas-liquid flow pattern in a microreactor system. Hassan et al. [22] described the flow pattern of gas-liquid inside the microreactor system by analyzing the literature data for gas-liquid systems and developed a universal map of gas-liquid flow regime (using the superficial velocity of gas and liquid as coordinates) to predict the flow pattern of the system. Note that, similar flow pattern maps were also found in the literature for different hydraulic diameters between $0.1 \mathrm{~mm}$ to $1 \mathrm{~mm}$, also with different materials $[23,24]$. Under the condition of high superficial velocity of gas and low superficial velocity of liquid, the slug-annular flow pattern was observed. This observation was confirmed by the experiment of Yue et al. [25], who studied the flow pattern of $\mathrm{CO}_{2}$-water inside a microchannel contractor with the hydraulic diameter of $0.667 \mathrm{~mm}$ and observed the slug-annular flow pattern when using high superficial velocity of gas and low superficial velocity of liquid. Our microreactor reactor had a hydraulic diameter of $0.5 \mathrm{~mm}$ and was operated with high superficial velocity of gas $\left(10-13 \mathrm{~m} \mathrm{~s}^{-1}\right)$ and high superficial velocity of liquid $\left(0.07-0.13 \mathrm{~m} \mathrm{~s}^{-1}\right)$. Under these conditions, our gas-liquid flow pattern would fall into the churn regime or slug-annular flow pattern, contributing to the large interfacial area between the liquid and gas phases [25].

\subsection{Correlation Model}

The correlation between the response (\%absorption efficiency) and the operating variables of our absorption system $\left(\mathrm{CO}_{2}\right.$ fraction $(\mathrm{F})$, total gas volumetric flow rate $(\mathrm{G})$, liquid volumetric flow rate $(\mathrm{L})$, and temperature (T)) was be evaluated by regression analysis. The result is shown in Equation (11). The optimization model indicated that the volumetric flow rate of gas and the volumetric flow rate of liquid strongly influenced the absorption efficiency. This was in agreement with the optimization of other absorption systems reported in the literature $[7,26]$. The precision of this model was verified based on the coefficient of determination $\left(R^{2}\right)$ by the parity plot between the experimental and predicted values in terms of the response parameter as shown in Figure $6 \mathrm{a}$. The $\mathrm{R}^{2}$ value of 0.9 suggested that the accuracy of model prediction was reasonable. 

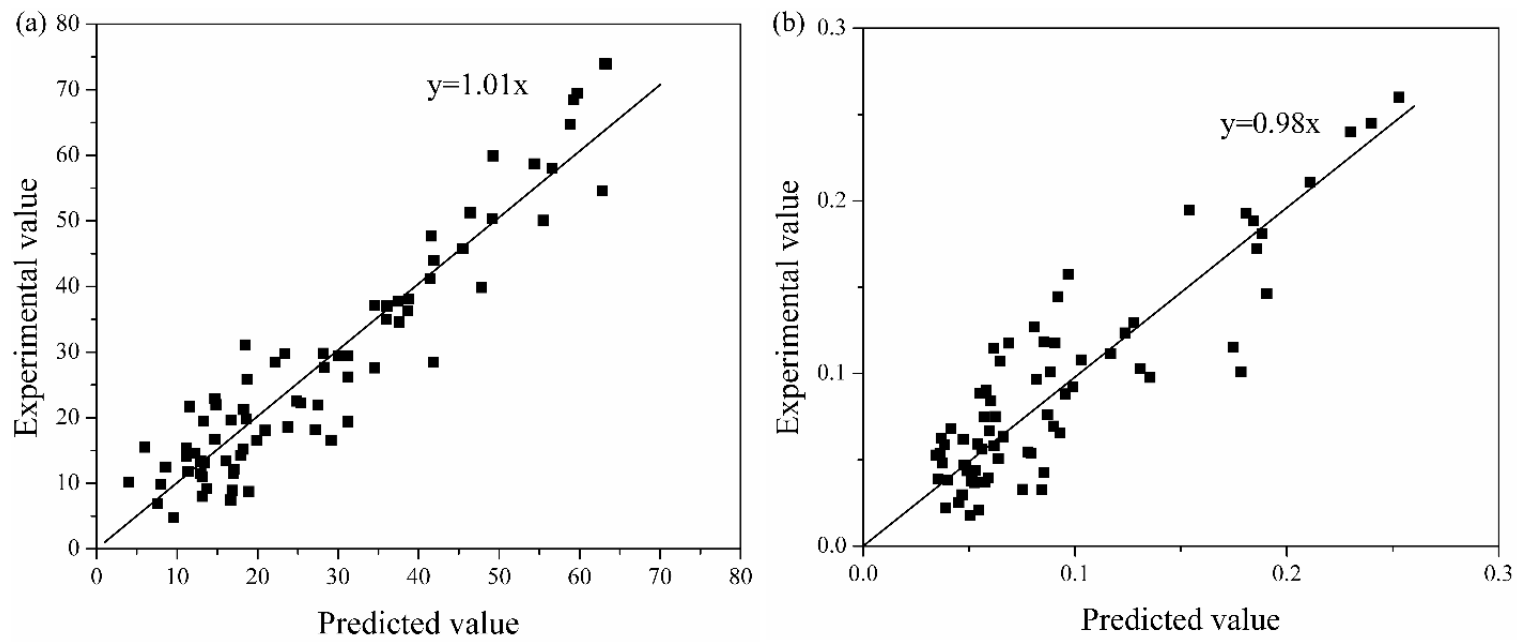

Figure 6. Parity plot of responses; (a) \%absorption efficiency (\%), (b) liquid-side volumetric mass transfer coefficient $\left(\mathrm{s}^{-1}\right)$.

The overall liquid-side volumetric mass transfer coefficient of the system $\left(\mathrm{K}_{\mathrm{L}} \mathrm{a}\right)$ can be expressed in terms of dimensionless parameters consisting of a group of physical properties and geometry of the system $[27,28]$, i.e., Reynold number (Re), Sherwood number (Sh), Schmidt number (Sc), and capillary number $(\mathrm{Ca})$. The correlation is presented in Equation (12). Note that, the $\mathrm{K}_{\mathrm{L}} \mathrm{a}$ is embedded in the Sherwood number as modified Sherwood number (Sh*) (see Equation (13)). The correlation of our model was in line with those reported in the literature [29,30].

The accuracy of this model was validated as presented in Figure $6 \mathrm{~b}$. The mean square errors (MSE) of the efficiency model and overall liquid-side volumetric mass transfer coefficient of the system were $4.1 \%$ and $4.9 \%$, respectively. The deviation of the model especially for the cases of low absorption efficiency and small $\mathrm{K}_{\mathrm{L}}$ a was possibly caused by the unstable pressure inside the system when the high volumetric flow rate of gas and liquid conditions were applied. The change of pressure can affect the hydrodynamic behavior, interfacial area, and mass transfer coefficient [31]. However, the effect of pressure on the absorption efficiency and $\mathrm{K}_{\mathrm{L}}$ a was little when compared to the other variables, i.e., temperature, and volumetric flow rate of gas and liquid [10].

$$
\begin{gathered}
\text { \%absorption efficiency }=595.16-0.45 \mathrm{~F}-3.98 \mathrm{G}-198.37 \mathrm{~L}-11.68 \mathrm{~T}+0.019 \mathrm{~F} \times \mathrm{G}-2.41 \mathrm{~F} \\
\times \mathrm{L}+0.07 \mathrm{~F} \times \mathrm{T}+1.50 \mathrm{G} \times \mathrm{L}+0.09 \mathrm{G} \times \mathrm{T}+3.36 \mathrm{~L} \times \mathrm{T}+0.004 \mathrm{~F} \times \mathrm{G} \times \mathrm{L}-0.0008 \mathrm{~F} \times \mathrm{G} \times \mathrm{T} \\
+0.03 \mathrm{~F} \times \mathrm{L} \times \mathrm{T}-0.03 \mathrm{G} \times \mathrm{L} \times \mathrm{T} \\
\mathrm{Sh}_{\mathrm{L}}^{*}=3.67 \mathrm{Re}_{\mathrm{G}}^{-0.26} \mathrm{Re}_{\mathrm{L}}^{-0.46} \mathrm{Sc}_{\mathrm{L}}^{0.44} \mathrm{Ca}_{\mathrm{L}}^{-1.31} \\
\mathrm{Sh}_{\mathrm{L}}^{*}=\frac{\mathrm{K}_{\mathrm{L}} \mathrm{aD}}{\mathrm{d}}
\end{gathered}
$$

\subsection{Optimization}

The objective function for optimization was set to maximize the absorption efficiency. The optimization was performed based on the response surface methodology and the optimal conditions with the maximum \%absorption of $70.9 \%$ were found at the temperature of $50{ }^{\circ} \mathrm{C}, \mathrm{CO}_{2}$ fraction of $53.7 \%$, the total volumetric flow rate of gas of $150 \mathrm{~mL} \mathrm{~min}^{-1}$, and the volumetric flow rate of water of $1 \mathrm{~mL} \mathrm{~min}^{-1}$. Under these conditions, $\mathrm{K}_{\mathrm{L}}$ a of $0.26 \mathrm{~s}^{-1}$ was calculated. This will be compared with other systems of $\mathrm{CO}_{2}$ absorption using water in Section 3.6. It is noted that this technique may be particularly useful for reducing the costs associated with chemical absorption for $\mathrm{CO}_{2}$ removal [32,33]. Although the quality 
of water in practical applications can also varied drastically such as tap water, underground water, and wastewater, this result can be used as a guideline for choosing the operating conditions.

\subsection{Comparison of the Liquid-Side Volumetric Mass Transfer Coefficient for Different Systems}

The performance of our system for $\mathrm{CO}_{2}$ capture application was compared with that of the other systems as summarized in Table 3. Although the pressure of the system was not the same in each absorption process, the effect of pressure on the $\mathrm{K}_{\mathrm{L}}$ was not significantly observed when the low pressure was used (1-2 bar). This was in line with several reports [10,34]. Note that, the effect of pressure on the $\mathrm{K}_{\mathrm{L}}$ would be noticeable when the absorption system is operated at pressures exceeding 10 bar [35].

As compared among different absorption systems, our system offered the largest $\mathrm{K}_{\mathrm{L}}$ a coefficient for $\mathrm{CO}_{2}$ absorption in water $\left(0.02-0.29 \mathrm{~s}^{-1}\right)$, implying superior $\mathrm{CO}_{2}$ capture efficiency. This was due to the unique characteristics of microchannels. For instance, high surface-to-volume ratio of microchannel $\left(3400-9000 \mathrm{~m}^{2} \mathrm{~m}^{-3}\right)$, which is considerably larger than the other absorption devices, promotes heat and mass transfer rates $[25,34]$. This was in line with the $\mathrm{K}_{\mathrm{L}}$ a results and surface-to-volume ratio of the other absorbers such as packed column $\left(0.0127 \mathrm{~s}^{-1}, 10-350 \mathrm{~m}^{2} \mathrm{~m}^{-3}\right)$ [36] and stirred tank $\left(0.0056-0.0333 \mathrm{~s}^{-1}\right.$, $100-2000 \mathrm{~m}^{2} \mathrm{~m}^{-3}$ ) [37]. Our work also presents a superior absorption performance when compared to the physical-chemical absorption in a microchamber reported by Zhu et al. [33] who investigated the $\mathrm{CO}_{2}$ capture efficiency under a broad range of gas volumetric flow rate (up to $300 \mathrm{~mL} \mathrm{~min}^{-1}$ ). Note that when the extremely short absorption time was applied, the physical absorption was dominant especially in the region of the high volumetric flow rate of gas and liquid. This was owing to the fact that the contact time in our system was longer, allowing for better performance. Lower absorption efficiency of our system compared to that of the hollow fiber membrane was because of the lower interfacial area of gas and liquid; however, the difficulty related to the flow bypassing and channeling of the liquid is a trade-off.

In terms of water utilization, our system offered much lower flow ratio between liquid and gas. Regarding the footprint, the size of absorber can be substantially reduced using microchannel absorber as compared to the conventional packed bed. For example, based on our experimental results, only a small bundle of approximately 454 microchannels operating in parallel can handle the input gas flow rate of $6.8 \times 10^{4} \mathrm{~mL} \mathrm{~min}^{-1}$. This small footprint also offers the potential for reduced power consumption, investment and maintenance cost. Therefore, microchannel can be effectively applied as an alternative device for $\mathrm{CO}_{2}$ capture applications.

Table 3. Comparison of $\mathrm{K}_{\mathrm{L}}$ a and efficiency for absorption system with the various reactor types.

\begin{tabular}{|c|c|c|c|c|}
\hline Reactor & Conditions & $\mathrm{K}_{\mathrm{L}} \mathrm{a}\left(\mathrm{s}^{-1}\right)$ & Efficiency (\%) & Reference \\
\hline Packed Tower & $\begin{array}{l}\text { System: } \mathrm{CO}_{2} \text {-water } \\
\text { Diameter of Column: } 30 \mathrm{~mm} \\
\text { Length of column: } 900 \mathrm{~mm} \\
\text { Gas flow rate: } 1000 \mathrm{~mL} \mathrm{~min}^{-1} \\
\text { Liquid flow rate: } 300 \mathrm{~mL} \mathrm{~min}^{-1} \\
\text { Temperature: } 25^{\circ} \mathrm{C} \\
\text { Pressure: } 1 \text { bar } \\
\text { GHSV: } 93.75 \mathrm{~h}^{-1} \\
\text { LHSV: } 28.125 \mathrm{~h}^{-1} \\
\text { Contact Time: } 30 \mathrm{~s}\end{array}$ & 0.0055 & - & [38] \\
\hline Well-mixed Reactor & 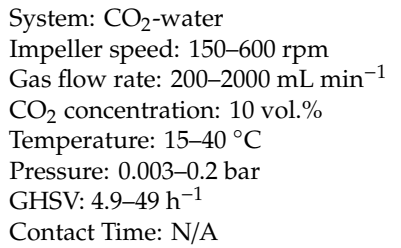 & $0.0056-0.0333$ & - & [39] \\
\hline
\end{tabular}


Table 3. Cont.

\begin{tabular}{|c|c|c|c|c|}
\hline Reactor & Conditions & $K_{L} a\left(s^{-1}\right)$ & Efficiency (\%) & Reference \\
\hline $\begin{array}{l}\text { Hollow Fiber } \\
\text { Membrane }\end{array}$ & $\begin{array}{l}\text { System: } \mathrm{CO}_{2} \text {-water } \\
\text { Length } 580 \mathrm{~mm} \text {, diameter } 25 \mathrm{~mm} \\
\text { Liquid Flow Rate: } 0.2-0.8 \mathrm{~L} \mathrm{~min}^{-1} \\
\text { Gas Flow Rate: } 0.7-2.8 \mathrm{~L} \mathrm{~min}^{-1} \\
\mathrm{CO}_{2} \text { concentration: } 40 \text { vol. } \% \\
\text { Temperature: } 25^{\circ} \mathrm{C}\end{array}$ & - & $55-97$ & [40] \\
\hline $\begin{array}{l}\text { Hollow Fiber } \\
\text { Membrane }\end{array}$ & $\begin{array}{l}\text { System: } \mathrm{CO}_{2} \text {-water } \\
\text { Length } 240 \mathrm{~mm} \text {, diameter } 36 \mathrm{~mm} \\
\text { Liquid Flow Rate: } 3 \times 10^{-3}-1 \times 10^{-2} \mathrm{~m} \mathrm{~s}^{-1} \\
\text { Gas Flow Rate: } 1 \times 10^{-4}-4 \times 10^{-4} \mathrm{~m} \mathrm{~s}^{-1} \\
\mathrm{CO}_{2} \text { concentration: } 30 \text { vol. } \% \\
\text { Temperature: } 22^{\circ} \mathrm{C}\end{array}$ & - & $10-80$ & [41] \\
\hline Microtube & $\begin{array}{l}\text { System: Air-water } \\
\text { Diameter of channel: } 1 \mathrm{~mm} \\
\text { Length of channel: } 200 \mathrm{~mm} \\
\text { Temperature: } 25^{\circ} \mathrm{C} \\
\text { Pressure: } 1 \text { bar } \\
\text { GHSV: } 1782 \mathrm{~h}^{-1} \\
\text { LHSV: } 15,330 \mathrm{~h}^{-1} \\
\text { Contact Time: } 1.08 \mathrm{~s}\end{array}$ & 0.38 & - & [42] \\
\hline Microchannel & $\begin{array}{l}\text { System: } \mathrm{CO}_{2}-\mathrm{NaOH} \\
\text { Width of channel: } 5.48 \mathrm{~mm} \\
\text { Depth of channel: } 1.05 \mathrm{~mm} \\
\text { Length of channel: } 90 \mathrm{~mm} \\
\text { Liquid Flow Rate: } 1.2-2.5 \mathrm{~mL} \mathrm{~min}^{-1} \\
\text { Gas Flow Rate: } 177-354 \mathrm{~mL} \mathrm{~min}{ }^{-1} \\
\mathrm{CO}_{2} \text { concentration: } 20 \mathrm{vol} . \% \\
\mathrm{NaOH} \text { concentration: } 2 \mathrm{M} \\
\text { Temperature: } 20^{\circ} \mathrm{C} \\
\text { Pressure: } 1 \text { bar }\end{array}$ & - & $15-50$ & [43] \\
\hline Microchannel a & $\begin{array}{l}\text { System: } \mathrm{CO}_{2} \text {-DEA } \\
\text { Diameter of channel: } 0.6 \mathrm{~mm} \\
\text { Length of channel: } 100 \mathrm{~mm} \\
\text { Liquid Flow Rate: } 0.9-1.2 \mathrm{~mL} \mathrm{~min}^{-1} \\
\text { Gas Flow Rate: } 150-300 \mathrm{~mL} \mathrm{~min}-1 \\
\mathrm{CO}_{2} \text { concentration: } 16.4 \mathrm{vol} \% \\
\text { DEA concentration: } 30 \mathrm{wt} \% \\
\text { Temperature: } 25^{\circ} \mathrm{C} \\
\text { Pressure: } 1 \text { bar } \\
\text { GHSV: } 3.18 \times 10^{5}-6.37 \times 10^{5} \mathrm{~h}^{-1} \\
\text { LHSV: } 1.91 \times 10^{3}-2.55 \times 10^{3} \mathrm{~h}^{-1} \\
\text { Contact Time: } 3.3 \times 10^{-5}-6.7 \times 10^{-5} \mathrm{~s}\end{array}$ & - & $5-10$ & [33] \\
\hline Microchannel & $\begin{array}{l}\text { System: } \mathrm{CO}_{2} \text {-water } \\
\text { Diameter of channel: } 0.5 \mathrm{~mm} \\
\text { Length of channel: } 60 \mathrm{~mm} \\
\text { Liquid Flow Rate: } 1-2 \mathrm{~mL} \mathrm{~min}{ }^{-1} \\
\text { Gas Flow Rate: } 150-200 \mathrm{~mL} \mathrm{~min}^{-1} \\
\text { CO }_{2} \text { concentration: } 40-60 \mathrm{vol} \% \\
\text { Temperature: } 30-50{ }^{\circ} \mathrm{C} \\
\text { Pressure: } 1.7 \text { bar } \\
\text { GHSV: } 6 \times 10^{5}-8 \times 10^{5} \mathrm{~h}^{-1} \\
\text { LHSV: } 4 \times 10^{3}-8 \times 10^{3} \mathrm{~h}^{-1} \\
\text { Contact Time: } 4.4 \times 10^{-3}-5.9 \times 10^{-3} \mathrm{~s}\end{array}$ & $0.02-0.26$ & $4.8-70.9$ & This work \\
\hline
\end{tabular}

${ }^{a}$ Physical-chemical absorption operated at high volumetric flow rate of gas and liquid.

\subsection{Physicochemical Absorption}

The findings from our experiments indicate that the maximum absorption efficiency of $70.9 \%$ (gas purity of $84 \%$ ) was obtained by using water as a green absorbent. Since the purity of product gas at the maximum absorption efficiency was lower than $90 \%$, we then extended our findings to the physicochemical absorption using MEA, where the required amount of solvent used significantly affects the process viability. Note that, in general chemisorption process, relatively high concentration of solvent is required to achieve high $\mathrm{CO}_{2}$ absorption efficiency, i.e., $30 \mathrm{wt}$.\% of MEA solution [3,4]. Our assumption was that a slight addition of chemical solvent (much less than what is commonly used) to our $\mathrm{CO}_{2}$ absorption system would fulfill the requirement in terms of absorption efficiency. 
To verify this statement, we adapted our $\mathrm{CO}_{2}$ absorption system by adding a little amount of MEA into the water. Three sets of experiment were carried out to demonstrate the possibility of using this system to further enhance the absorption efficiency. The experiments were carried out at constant temperature of $40^{\circ} \mathrm{C}$, MEA concentration of $2.2 \mathrm{M}\left(1: 1\right.$ molar ratio of MEA-to- $\left.\mathrm{CO}_{2}\right)$, liquid flow rate of $1 \mathrm{~mL} \mathrm{~min}{ }^{-1}$, and volumetric flow rate of gas of $150 \mathrm{~mL} \mathrm{~min}^{-1}$, while the $\mathrm{CO}_{2}$ fraction (40-60 vol.\%) were varied. As shown in Figure 7, the addition of small amount of MEA could significantly enhance the \%absorption by more than $37 \%$ for various levels of $\mathrm{CO}_{2}$ feed concentration. For example, for the $\mathrm{CO}_{2}$ fraction of $40 \%$, using MEA of $1 \mathrm{~mol} \%$ could enhance the \%absorption from $56.2 \%$ to $80.2 \%$, suggesting that small amount of solvent was adequate to achieve high absorption efficiency. It is also possible to extend our findings for the application $\mathrm{CO}_{2}$ absorption using wastewater containing ammonia which can be related to many industries such as fertilizer, rubber processing, leather manufacturing, etc. However, this requires further investigation on the effect of operating conditions and characteristics of absorbent on the efficiency of $\mathrm{CO}_{2}$ absorption.

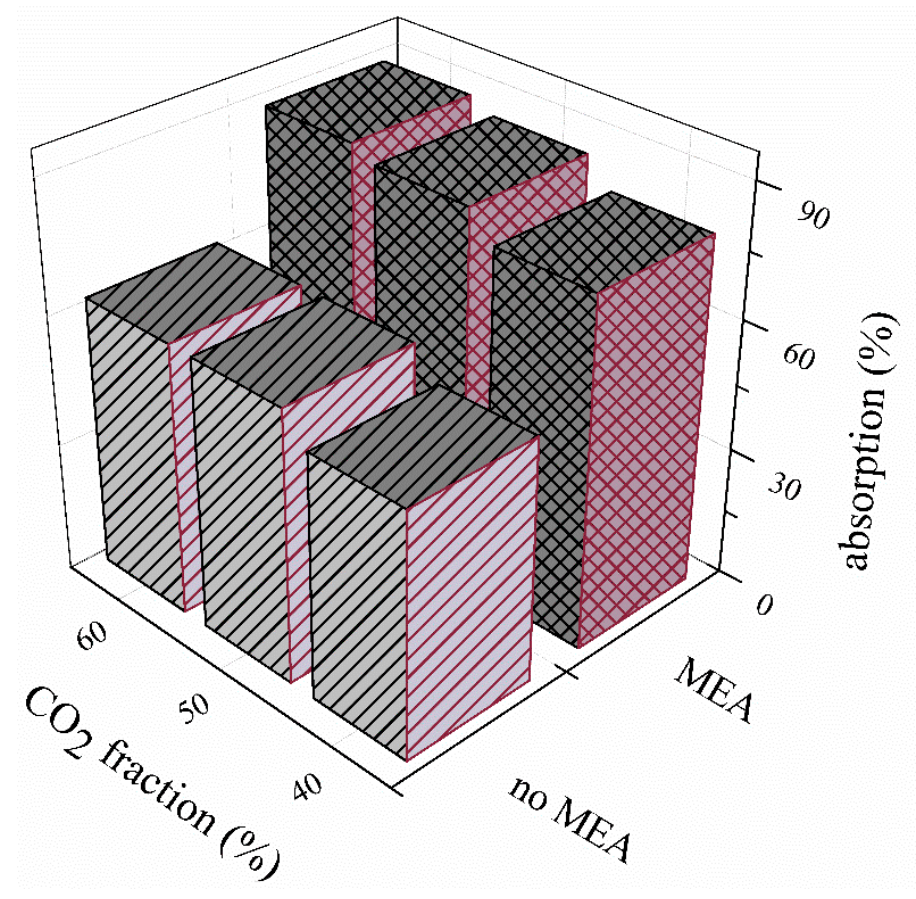

Figure 7. Effect of MEA addition on the \%absorption under various $\mathrm{CO}_{2}$ fractions.

\section{Conclusions}

The findings of this work indicate that the absorption of $\mathrm{CO}_{2}$ from the gas using water in a microchannel contactor was efficient compared to other absorbers in terms of the overall liquid-side volumetric mass transfer coefficient. The influence of operating conditions including temperature, gas and liquid volumetric flow rate on the \%absorption and overall liquid-side volumetric mass transfer coefficient was significant. The maximum \%absorption of $70.9 \%$ was achieved at temperature of $50{ }^{\circ} \mathrm{C}, \mathrm{CO}_{2}$ fraction of $53.7 \%$, total volumetric flow rate of gas of $150 \mathrm{~mL} \mathrm{~min}{ }^{-1}$, and volumetric flow rate of water of $1 \mathrm{~mL} \mathrm{~min}{ }^{-1}$. It was also demonstrated that this system can be much improved by adding little amount of MEA in the liquid absorbent. The \%absorption up to $88 \%$ was achieved by using 2.2 M of MEA (1:1 molar ratio of MEA-to- $\left.\mathrm{CO}_{2}\right)$.

Author Contributions: Conceptualization, N.A., A.K. and A.J.; methodology, N.A., A.K. and A.J.; investigation N.A., A.K. and A.J.; resources, A.J.; writing-original draft preparation, N.A.; writing-review and editing, N.A., W.N., A.K. and A.J.; visualization, N.A., W.N. and A.J.; supervision, A.K. and A.J.; project administration, A.J.; funding acquisition, A.J. All authors have read and agreed to the published version of the manuscript.

Funding: This research was funded by Kasetsart University Research and Development Institute (KURDI). 
Acknowledgments: Financial support from Kasetsart University Research and Development Institute was acknowledged.

Conflicts of Interest: The authors declare no conflict of interest.

\section{Nomenclature and Units}

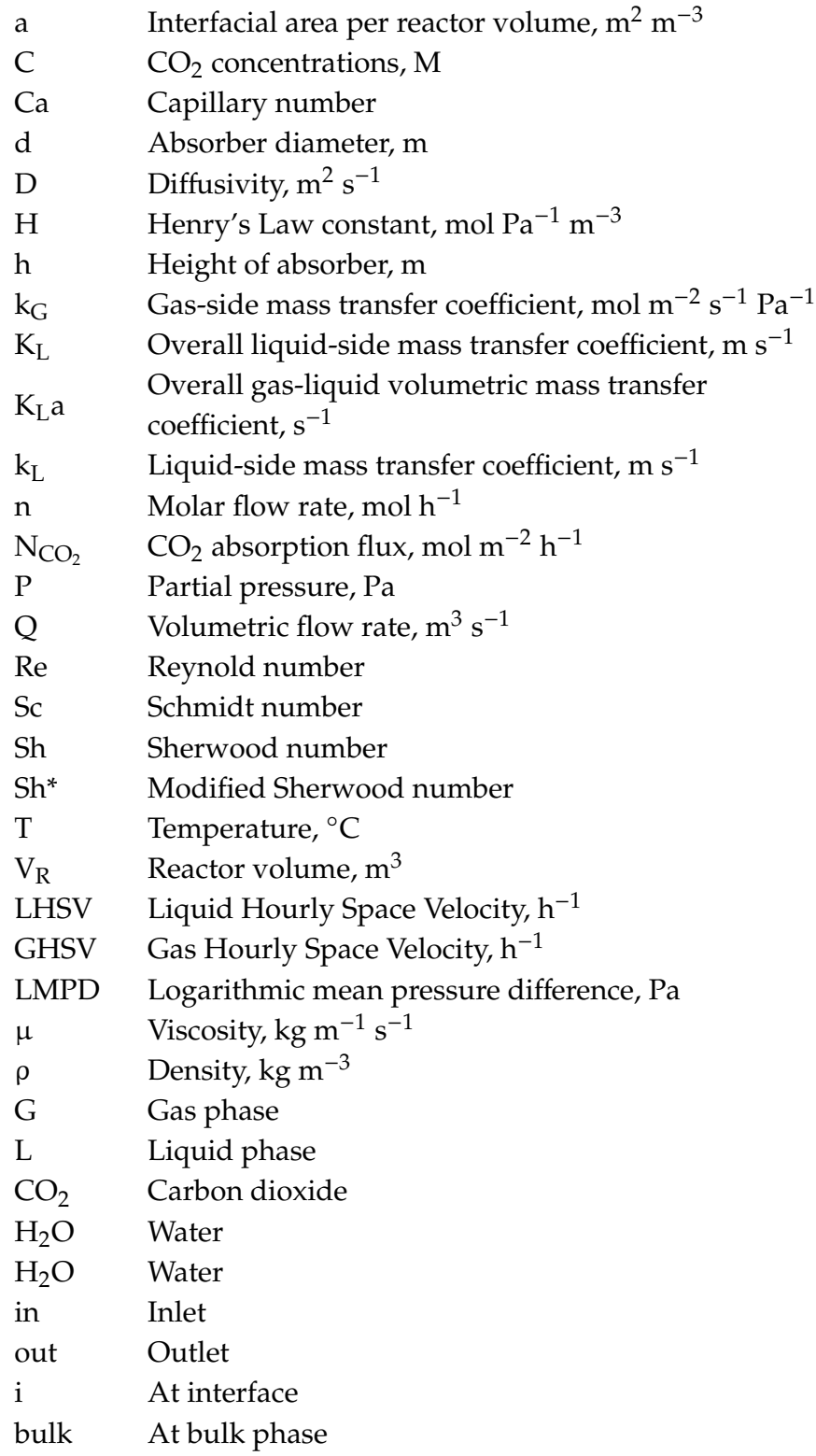

\section{References}

1. Noorollahi, Y.; Kheirrouz, M.; Asl, H.F.; Yousefi, H.; Hajinezhatd, A. Biogas production potential from livestock manure in Iran. Renew. Sustain. Energ. Rev. 2015, 50, 748-754. [CrossRef]

2. Khraisheh, M.; Mukherjee, S.; Kumar, A.; Momani, F.A.; Walker, G.; Zaworotko, M.J. An overview on trace $\mathrm{CO}_{2}$ removal by advanced physisorbent materials. J. Environ. Manag. 2020, 255, 109874. [CrossRef] [PubMed]

3. Pashaei, H.; Ghaemi, A. $\mathrm{CO}_{2}$ absorption into aqueous diethanolamine solution with nano heavy metal oxide particles using stirrer bubble column: Hydrodynamics and mass transfer. J. Environ. Chem. Eng. 2020, 8, 104110. [CrossRef]

4. Ma, D.; Zhu, C.; Fu, T.; Yuan, X.; Ma, Y. An effective hybrid solvent of MEA/DEEA for $\mathrm{CO}_{2}$ absorption and its mass transfer performance in microreactor. Sep. Purif. Technol. 2020, 242, 116795. [CrossRef] 
5. Sahraie, S.; Rashidi, H.; Sheyda, P.V. An optimization framework to investigate the $\mathrm{CO}_{2}$ capture performance by MEA: Experimental and statistical studies using Box-Behnken design. Process Saf. Environ. Prot. 2019, 122, 161-168. [CrossRef]

6. Hemmati, A.; Rashidi, H.; Behradfar, K.; Kazem, A. A comparative study of different mass transfer and liquid hold-up correlations in modeling $\mathrm{CO}_{2}$ absorption with MEA. J. Nat. Gas Sci. Eng. 2019, 62, 92-100. [CrossRef]

7. Chen, P.C.; Lin, S.Z. Optimization in the absorption and desorption of $\mathrm{CO}_{2}$ using sodium glycinate solution. Appl. Sci. 2018, 8, 2041. [CrossRef]

8. Xu, M.; Wang, S.; Xu, L. Screening of physical-chemical biphasic solvents for $\mathrm{CO}_{2}$ absorption. Int. J. Greenh . Gas Control 2019, 85, 199-205. [CrossRef]

9. Aghel, B.; Heidaryan, E.; Sahraie, S.; Mir, S. Application of the microchannel reactor to carbon dioxide absorption. J. Clean. Prod. 2019, 231, 723-732. [CrossRef]

10. Akkarawatkhoosith, N.; Kaewchada, A.; Jaree, A. High-throughput $\mathrm{CO}_{2}$ capture for biogas purification using monoethanolamine in a microtube contactor. J. Taiwan Inst. Chem. Eng. 2019, 98, 113-123. [CrossRef]

11. Remacha, M.J.N.; Kulkarni, A.A.; Jensen, K.F. Gas-liquid flow and mass transfer in an advanced-flow reactor. Ind. Eng. Chem. Res. 2013, 52, 8996-9010. [CrossRef]

12. Luo, X.; Hartono, A.; Svendsen, H.F. Comparative kinetics of carbon dioxide absorption in unloaded aqueous monoethanolamine solutions using wetted wall and string of discs columns. Chem. Eng. Sci. 2012, 82, 31-43. [CrossRef]

13. Yusof, S.M.M.; Lau, K.K.; Shariff, A.M.; Tay, W.H.; Mustafa, N.F.A.; Lock, S.S.M. Novel continuous ultrasonic contactor system for $\mathrm{CO}_{2}$ absorption: Parametric and optimization study. J. Ind. Eng. Chem. 2019, 79, $279-287$. [CrossRef]

14. Wangfeng, C.; Jiao, Z.; Xubin, Z.; Yan, W. Enhancement of $\mathrm{CO}_{2}$ absorption under taylor flow in the presence of fine particles. Chin. J. Chem. Eng. 2013, 21, 135-143.

15. Luo, X.; Hartono, A.; Hussain, S.; Svendsen, H.F. Mass transfer and kinetics of carbon dioxide absorption into loaded aqueous monoethanolamine solutions. Chem. Eng. Sci. 2015, 123, 57-69. [CrossRef]

16. Versteeg, G.F.; Swaaij, W.P.M.V. Solubility and diffusivity of acid gases (COP, N20) in aqueous alkanolamine solutions. J. Chem. Eng. Data 1988, 33, 29-34. [CrossRef]

17. Karlsson, H.; Svensson, $\mathrm{H}$. Rate of absorption for $\mathrm{CO}_{2}$ absorption systems using a wetted wall column. Energy Procedia 2017, 114, 2009-2023. [CrossRef]

18. Bhaduri, G.A.; Siller, L. Nickel nanoparticles catalyse reversible hydration of carbon dioxide for mineralization carbon capture and storage. Catal. Sci. Technol. 2013, 3, 1234-1239. [CrossRef]

19. Cadogan, S.P.; Maitland, G.C.; Trusler, J.P.M. Diffusion Coefficients of $\mathrm{CO}_{2}$ and $\mathrm{N}_{2}$ in Water at Temperatures between 298.15 K and 423.15 K at Pressures up to $45 \mathrm{MPa}$. J. Chem. Eng. Data 2014, 59, 519-525. [CrossRef]

20. Mansourizadeh, A.; Ismail, A.F.; Matsuura, T. Effect of operating conditions on the physical and chemical $\mathrm{CO}_{2}$ absorption through the PVDF hollow fiber membrane contactor. J. Membr. Sci. 2010, 353, 192-200. [CrossRef]

21. Diamond, L.W.; Akinfiev, N.N. Solubility of $\mathrm{CO}_{2}$ in water from -1.5 to $100{ }^{\circ} \mathrm{C}$ and from 0.1 to $100 \mathrm{MPa}$ : Evaluation of literature data and thermodynamic modelling. Fluid Phase Equilibria 2003, 208, 265-290. [CrossRef]

22. Hassan, I.; Vaillancourt, M.; Pehlivan, K. Two-phase flow regime transitions in microchannels: A comparative experimental study. Microscale Thermophys. Eng. 2005, 9, 165-182. [CrossRef]

23. Kashid, M.N.; Renken, A.; Minsker, L.K. Gas-liquid and liquid-liquid mass transfer in microstructured reactors. Chem. Eng. Sci. 2011, 66, 3876-3897. [CrossRef]

24. Shao, N.; Gavriilidis, A.; Angeli, P. Flow regimes for adiabatic gas-liquid flow in microchannels. Chem. Eng. Sci. 2009, 64, 2749-2761. [CrossRef]

25. Yue, J.; Chen, G.; Yuan, Q.; Luo, L.; Gonthier, Y. Hydrodynamics and mass transfer characteristics in gas-liquid flow through a rectangular microchannel. Chem. Eng. Sci. 2007, 62, 2096-2108. [CrossRef]

26. Sheyda, P.V.; Afshari, A. A detailed screening on the mass transfer modeling of the $\mathrm{CO}_{2}$ absorption utilizing silica nanofluid in a wetted wall column. Process Saf. Environ. Prot. 2019, 127, 125-132. [CrossRef]

27. Puxty, G.; Rowland, R.; Attalla, M. Comparison of the rate of $\mathrm{CO}_{2}$ absorption in to aqueous ammonia and monoethanolamine. Chem. Eng. Sci. 2010, 65, 915-992. [CrossRef] 
28. Arachchige, U.S.P.R.; Aryal, N.; Eimer, D.A.; Melaaen, M.C. Viscosities of pure and aqueous solutions of monoethanolamine (MEA), diethanolamine (DEA) and N-methyldiethanolamine (MDEA). Nord. Rheol. Soc. 2013, 21, 299-306.

29. Li, C.; Zhu, C.; Ma, Y.; Liu, D.; Gao, X. Experimental study on volumetric mass transfer coefficient of $\mathrm{CO}_{2}$ absorption into MEA aqueous solution in a rectangular microchannel reactor. Int. J. Heat Mass Transf. 2014, 78, 1055-1059. [CrossRef]

30. Ji, X.Y.; Ma, Y.G.; Fu, T.T.; Zhu, C.Y.; Wang, D.J. Experimental investigation on liquid volumetric mass transfer coefficient for upward gas-liquid two-phase flow in rectangular microchannels. Br. J. Chem. Eng. 2010, 27, 573-582. [CrossRef]

31. Isa, F.; Suleman, H.; Zabiri, H.; Maulud, A.S.; Ramasamy, M.; Tufa, L.D.; Shariff, A.M. An overview on $\mathrm{CO}_{2}$ removal via absorption: Effect of elevated pressures in counter-current packed column. J. Nat. Gas Sci. Eng. 2016, 33, 666-677. [CrossRef]

32. Guangwen, C.; Jun, Y.; Quan, Y. Gas-Liquid Microreaction Technology: Recent Developments and Future Challenges. Chin. J. Chem. Eng. 2008, 16, 663-669.

33. Zhu, K.; Yao, C.; Liu, Y.; Chen, G. Theoretical approach to $\mathrm{CO}_{2}$ absorption in microreactors and reactor volume prediction. Chem. Eng. Process. 2020, 150, 107904. [CrossRef]

34. Elhajj, J.; Hindi, M.A.; Azizi, F. A Review of the absorption and desorption processes of carbon dioxide in water systems. Ind. Eng. Chem. Res. 2014, 53, 2-22. [CrossRef]

35. Yao, C.; Dong, Z.; Zhao, Y.; Chen, G. Gas-liquid flow and mass transfer in a microchannel under elevated pressures. Chem. Eng. Sci. 2015, 123, 137-145. [CrossRef]

36. Charpentier, J.C. Mass-transfer rates in gas-liquid absorbers and reactors. Adv. Chem. Eng. 1981, 11, 1-133.

37. Kies, F.K.; Benadda, B.; Otterbein, M. Experimental study on mass transfer of a co-current gas-liquid contactor performing under high gas velocities. Chem. Eng. Process. 2004, 43, 1389-1395. [CrossRef]

38. Salimi, J.; Salimi, F. $\mathrm{CO}_{2}$ capture by water-based $\mathrm{Al}_{2} \mathrm{O}_{3}$ and $\mathrm{Al}_{2} \mathrm{O}_{3}-\mathrm{SiO}_{2}$ mixture nanofluids in an absorption packed column. Rev. Mex. Ing. Quim. 2016, 15, 185-192.

39. Hill, G.A. measurement of overall volumetric mass transfer coefficients for carbon dioxide in a well-mixed reactor using a pH probe. Ind. Eng. Chem. Res. 2006, 45, 5796-5800. [CrossRef]

40. Wang, F.; Kang, G.; Liu, D.; Li, M.; Cao, Y. Enhancing $\mathrm{CO}_{2}$ Absorption Efficiency Using a Novel PTFE Hollow Fiber Membrane Contactor at Elevated Pressure. AIChE J. 2018, 64, 2135-2145. [CrossRef]

41. Belaissaoui, B.; Baro, J.C.; Hernando, A.L.; Zaidiza, D.A.; Chabanon, E.; Castel, C.; Rode, S.; Roizard, D.; Favre, E. Potentialities of a dense skin hollow fiber membrane contactor for biogas purification by pressurized water absorption. J. Membr. Sci. 2016, 513, 236-249. [CrossRef]

42. Vandu, C.O.; Liu, H.; Krishna, R. Mass transfer from Taylor bubbles rising in single capillaries. Chem. Eng. Sci. 2005, 60, 6430-6437. [CrossRef]

43. Constantinou, A.; Gavriilidis, A. $\mathrm{CO}_{2}$ absorption in a microstructured mesh reactor. Ind. Eng. Chem. Res. 2010, 49, 1041-1049. [CrossRef]

Publisher's Note: MDPI stays neutral with regard to jurisdictional claims in published maps and institutional affiliations.

(C) 2020 by the authors. Licensee MDPI, Basel, Switzerland. This article is an open access article distributed under the terms and conditions of the Creative Commons Attribution (CC BY) license (http://creativecommons.org/licenses/by/4.0/). 